NBER WORKING PAPER SERIES

\title{
LETTING STATES DO THE DIRTY WORK: \\ STATE RESPONSIBILITY FOR FEDERAL ENVIRONMENTAL REGULATION
}

\author{
Hilary Sigman \\ Working Paper 9451 \\ http://www.nber.org/papers/w9451 \\ NATIONAL BUREAU OF ECONOMIC RESEARCH \\ 1050 Massachusetts Avenue \\ Cambridge, MA 02138 \\ January 2003
}

I am grateful to Rosanne Altshuler for comments and to George Joseph for research assistance. This research is supported in part by grant number SES-9876498 from the National Science Foundation. The views expressed herein are those of the authors and not necessarily those of the National Bureau of Economic Research.

(C2003 by Hilary Sigman. All rights reserved. Short sections of text not to exceed two paragraphs, may be quoted without explicit permission provided that full credit including notice, is given to the source. 
Letting States do the Dirty Work: State Responsibility for Federal Environmental Regulation Hilary Sigman

NBER Working Paper No. 9451

January 2003

JEL No. Q28, H77

\title{
$\underline{\text { ABSTRACT }}$
}

Under most U.S. environmental regulations, the federal government shares responsibility with the states by authorizing them to implement and enforce federal policies. Authorization provides states with considerable discretion over the effects of regulation and is perhaps the most significant decentralization in U.S. environmental policy. However, few studies address its role. To fill this gap, this paper explores the empirical determinants of authorization for water pollution and hazardous waste regulation. Although no single hypothesis strongly explains authorization, I find some evidence that states authorize to increase the stringency of regulation, which suggests that environmental decentralization would be beneficial.

\author{
Hilary Sigman \\ Department of Economics \\ Rutgers University \\ 75 Hamilton Street \\ New Brunswick, NJ 08901-1248 \\ and NBER \\ sigman@economics.rutgers.edu
}


Although major environmental regulation in the United States derives from federal statutes, states conduct most of the day-to-day business of implementing, monitoring, and enforcing regulation. The federal government explicitly delegates these functions to states by granting them a status known as "authorization" or "primacy." This delegation occurs under water pollution regulations (the Clean Water Act, CWA), hazardous waste regulations (the Resource Conservation and Recovery Act, RCRA) and regulations for drinking water, toxic substances, and pesticides. ${ }^{1}$ When the state has not received authorization, the federal government implements and enforces policies through one of ten regional EPA offices.

This paper explores the empirical determinants and effects of state authorization. Assessments of environmental policy often mention the state role, yet go on to ignore it and treat federal programs as uniform. Although authorization sounds like a bureaucratic abstraction, it is a meaningful policy distinction and deserves study for a few reasons.

First, authorization may be important in its own right. If states differ from the federal government and each other in their implementation and enforcement, state authorization could have a major effect on the outcomes of environmental policy. For example, some observers blame authorization for poor enforcement of environmental law, although the states disagree (Flatt, 1997; Farber, 1997; ECOS, 2001).

Second, authorization offers a rare window into the decentralized alternative to current environmental policy-making. If we determine why states want to receive authorization and what they do with this responsibility, we may infer the implications of expanding their influence. For example, evidence that states authorize to free ride on their neighbors would suggest a bleaker picture for decentralization than evidence that they authorize to provide stronger environmental controls than the federal government. Thus, understanding environmental authorization may provide insight into the desirability of decentralization of public policies in practice.

\footnotetext{
${ }^{1}$ For the status of state programs under all federal environmental statutes, see the Environmental Council of the State website (www.sso.org/ecos). For studies of authorization for policies not studied here, see Grossman (1995), who discusses the institutional arrangements for regulation of pesticides, and U.S. GAO (1995), which finds that authorized states lack the resources to implement drinking water requirements.
} 
This paper examines authorization under CWA and RCRA, the two most important environmental regulations under which states receive authorization. ${ }^{2}$ The next section describes the meaning of authorization under CWA and RCRA and the authorization process. The second section presents data on current authorization status. The third section advances hypotheses about the determinants of authorization, drawing from previous literature on federalism. It examines the patterns in the extent and timing of authorization for evidence to support these hypotheses. The fourth section discusses previous empirical work on the effects of authorization. The final section summarizes the implications for environmental federalism and directions for future research.

\section{The role of authorization}

Pollution control regulation involves three parts: the setting of standards, implementation of standards, and monitoring and enforcement. Authorized states have primary control over the latter two functions. Despite apparent strictures from federal standards, I argue in this section that control over these functions gives states considerable latitude and is therefore an important aspect of environmental regulation in practice.

First, implementation often involves translating federal standards into permits for allowable pollution issued to major sources. For water pollution, permit writing confers substantial discretion. Major industrial and municipal water polluters receive permits that set numerical discharge limits for the facility (Freeman, 2000). The regulator establishes these numerical limits based on a federal standard for the pollution abatement technology, with tighter limits required if the abatement technology would not assure sufficient water quality. Applying the technology standard and, especially, the water quality standard to specific plants allows the state discretion. Permits are subject to negotiation between polluter and regulator and to public comment periods (which would be unnecessary were permit levels mechanically derived from federal rules).

\footnotetext{
${ }^{2}$ The third major pollution control statute, the Clean Air Act, also delegates responsibility to the states, but in a different manner. It requires states to file and obtain federal approval for State Implementation Plans (SIPs), giving them responsibility by default, unlike the authorization under CWA and RCRA for which federal responsibility is the default. Whether the difference between these two approaches has a meaningful effect on the results of the policy is an open question.
} 
There is significant variation in permit discharge limits. For example, the GAO studied permit limits for metals (U.S. GAO, 1996). It examined municipal facilities discharging between 1.4 and 2.5 million gallons per day into freshwater. Table 1 reports the GAO's summary data. As the table reports, the allowable pollution varies by more than one order of magnitude for most metals, despite the similar size of the facilities. The table also reports the states that are responsible for the highest and lowest standards; West Virginia appears to have high variability for unexplained reasons.

Hazardous waste facilities also require permits, but regulators have much less discretion in writing hazardous waste permits than water pollution permits. RCRA permits mostly rely directly on federal technology standards, rather than translating this standard into an emission limit. The permits are based on technology or performance rules that do not depend on the resulting pollution concentrations in the environment, unlike CWA in-stream water quality standards.

In addition to discretion in permit writing, authorization also gives states control over monitoring and enforcement. Authorized states may set the monitoring frequency and other dimensions of the intensity of monitoring, such as whether visits are announced in advance and whether plants once out of compliance receive more attention. Authorized states also have the first opportunity to bring enforcement actions when noncompliance is detected, including notices of violation and fines. The federal government also may bring enforcement actions after some delay, if the state does not, but uses this privilege infrequently (Helland, 1998). Thus, authorization provides states significant influence over the rules that facilities face and the enforcement threat behind those rules.

This discretion does have costs. Authorized states must find the resources to manage the programs in place of the federal government, which may shift resources away from state priorities. For example, in a GAO survey of state RCRA program managers, 75 percent reported that they would like more resources to monitor small quantity generators, who may be responsible for most illegal dumping, but are thwarted by a federal requirement that large quantity generators receive annual inspection (U.S. GAO, 1995). Under RCRA, authorized states may receive program funding from the federal government, but must provide a minimum of 25 percent of their administrative costs. 
To receive authorization under CWA and RCRA, the state must submit paperwork requesting authorization, demonstrating both the ability and legal authority to conduct its own program. The program must be consistent with and at least as stringent and broad in scope as the federal rules. If the EPA Administrator approves the application, the state program supplants the federal permit program. The federal government may suspend state authorization if the state program fails to meet the federal requirements; however, it has never done so in practice. It is politically difficult and legally complex for EPA to rescind these privileges (Flatt, 1997). In addition, federal officials dread the expense of resuming responsibility (U.S. GAO, 1995).

\section{Authorization status}

Authorization is not a simple binary matter. Under the Clean Water Act, states receive authority for five different parts of the program. Figure 1 shows a count of the number of the five programs for which the state has received authorization. All but six states currently have authorization for the basic permit program (National Pollution Discharge Elimination System, or NPDES) for industrial and municipal sources. The remaining components of the program for which states may receive authorization are general permitting, the NPDES program for federal facilities, pretreatment program, and the biosolids (sewage sludge) program. Table 2 reports the frequency of various combinations of authorized programs. The dates of authorization differ across the various programs, although there appears to be some economy of scale in authorization because states often authorize for several programs at once.

Authorization status under the Resource Conservation and Recovery Act (RCRA) is more complicated. States must separately apply for authorization of regulations as revised regulations are issued. To summarize this information, the EPA reports an authorization percentage, representing the share of the rules (202 in March 2002) that the state has adopted. This percentage does not weight the rules by importance, but is the 
best summary available. ${ }^{3}$ Figure 2 reports each state's quartile in the distribution of RCRA authorization percentages.

The correlation between RCRA authorization percentage and the number of CWA programs authorized is surprisingly low, .16, although one state, Alaska, is not authorized for either program. The low correlation suggests that the determinants of authorization are idiosyncratic to particular programs and may make it difficult to draw general conclusions about the role of authorization.

\section{Determinants of state authorization}

States may wish to be authorized for many reasons. ${ }^{4}$ I categorize states' possible motivations into three groups, acknowledging significant overlap among the groups. The rationales are: (i) desiring a different stringency, either weaker or stronger than federal regulations; (ii) desiring a different targeting of controls because of different objectives or information; and/or (iii) desiring authorization for reasons related to the regulatory bureaucracy rather than the effects on pollution control. This section discusses the relationship of each rationale to the federalism literature and considers the empirical evidence to support the rationale.

\section{A. Differences in desired stringency}

Authorization is useful to states that desire both more and less stringency. A state that desires to increase stringency will find authorization attractive to streamline regulation. By authorizing, the state avoids the administrative costs of implementing more stringent requirements outside the auspices of the federal program.

States may also use authorization to relax the effects of the regulation. They may use subtle means, such as writing relatively lax permits or providing warning before inspections. But no subtly may be necessary: authorization is a one-way street, almost

\footnotetext{
${ }^{3}$ Alaska and Iowa are not yet authorized at all, although the EPA does document that Alaska has rules that match some of the federal regulations. New Mexico's authorization exceeds $100 \%$, presumably because the numerator includes some "optional" rules (rules that reduced the stringency or breadth of RCRA) that are excluded from the denominator.

${ }^{4}$ Unless the EPA is capricious in its standards for authorization, states should know the necessary threshold and, thus, their desire to authorize should be the principal determining factor. See below for some evidence on the intertemporal consistency of EPA's decisions.
} 
impossible to rescind. For example, GAO (1996) reports that Arkansas refuses to impose federal discharge limits and monitoring requirements for municipal water pollution sources because they are "too strict" and would subject the state to litigation. The regional EPA office says its "only recourse would be to take back responsibility for the program --- an unrealistic option (U.S. GAO, 1996, pp. 6).” Thus, once authorized, states have quite a free hand to conduct (or ignore) the program.

The previous literature suggests several reasons for a state to desire different stringency than the federal government chooses for it. These reasons have different empirical implications and thus should be distinguished.

One set of explanations results from the tendency for federal regulations, including CWA and RCRA, to rely on nationally uniform standards. In principle, uniformity is not a necessary feature of centralization. ${ }^{5}$ In practice, however, political factors seem to limit the differentiation in federal standards, resulting in costly uniformity (Dinan et al., 1999).

With such uniformity in standards, simple heterogeneity among states will motivate states to authorize (and justify allowing them to do so). ${ }^{6}$ If environmental policies are chosen for the median state, states on both ends of the desired stringency distribution will wish greater discretion (a "U-shaped" hypothesis). Alternatively, some authors argue that environmental policies are chosen by states desiring stringent regulations. Legislators from these states use federal minimum standards to reduce economic competition from states that would otherwise impose lower compliance costs (Crandall, 1983; Pashigian, 1985). Under this hypothesis, states wishing low stringency are least satisfied with federal control. As a result, we would not expect a U-shape in authorization, but rather concentration of authorization among states with the lowest desired stringency. To test these hypotheses, I examine the association between authorization and the greenness of a state's preferences (as a measure of desired stringency).

However, the previous literature also suggests that states may desire a different stringency, even in the absence of uniform federal standard. First, if states compete against one another in attracting economic activity, the destructive competition familiar

\footnotetext{
${ }^{5}$ Besley and Coate (1999) present a model that does not require uniformity in centralized policy (or local informational advantages), but still find advantages of decentralization because decisions by the federal legislature do not conform to the state's own preferences.
} 
from the fiscal competition literature may arise (see for example, Oates (1999) and Wilson (1999) for fiscal competition and Oates (2001) and Levinson (2003) for environmental competition). Second, the political processes in the states may differ from the federal government in ways that cause them to choose different stringencies. A few authors suggest that industry groups experience a relative advantage in state decision-making compared to federal decision-making. ${ }^{7}$ Unlike the hypotheses above, these hypotheses would not associate authorization with preferences that predict the desired stringency. Instead, we need to look at the outcome of authorization to determine if competition or these political imbalances appear to enter states' actions.

\section{Authorization and green preferences.}

To explore the hypothesis that desired stringency affects authorization, I use two measures of the greenness of preferences: the League of Conservation Voters (LCV) score for the state's House delegation in 2000 and membership in three major national environmental organizations in the late 1980s (Hall and Kerr, 1990). ${ }^{8}$ Because it reflects the outcome of political decision-making in the state, the LCV may measure the greenness of the state's median voter and thus may be the best measure for the current purpose. The correlation between LCV score and conservation group membership is .6, but notably (unauthorized) Alaska has high environmental membership and very low LCV scores.

Table 3 examines the evidence for a U-shape in authorization using the LCV scores and several measures of authorization. The first measure of CWA authorization is whether the state had received authorization for the base CWA permit program for industrial and municipal sources (NPDES) by 2002. This program is the core of the federal water pollution control and may be the most meaningful component of authorization. In Table 3, states without authorization are concentrated in the lowest

\footnotetext{
${ }^{6}$ Strumpf and Oberholzer-Gee (2002) find empirical evidence to support the positive claim that heterogeneity encourages decentralization in the institutions for control of liquor sales.

${ }^{7}$ This view does not seem to have been formalized, but for informal discussions see Esty (1996) and a critical examination by Revesz (2001).

${ }^{8}$ The LCV score is the proportion of the time that the member of Congress voted with the LCV's position on legislation with environmental consequences.
} 
quartile of LCV scores. There is no evidence of a U-shaped pattern, so the principal question is whether there is a statistically significant positive association.

Table 4 contains a test to answer this question. The table presents differences in means for LCV scores (and other state characteristics studied below) for states authorized for the base NPDES program, compared with the 6 states that do not have authorization. A t-test does not reject the hypothesis that the mean scores are the same at conventional significance levels. There is also no statistically significant difference in conservation group membership between the groups.

A second measure of authorization is the year of authorization for the base CWA program. States with greater benefits from authorization would likely have applied for and received it earlier. The first states received authorization in 1973 and most states had authorized by 1976. States with low LCV scores authorized much later on average than the remaining states, but the correlation between LCV score and date of authorization is not statistically significant (Table 5). There is, however, a negative and statistically significant correlation between conservation group membership and time of authorization. This negative correlation would suggest authorization to increase stringency.

The third measure of CWA authorization is the total number of programs authorized for the state, ranging from zero to five. No association is evident in Table 3, nor is there a correlation with LCV scores in Table 5. However, conservation group membership is negatively correlated with the extent of authorization. Although this result seems inconsistent with earlier authorization by greener states above, it may be part of the same phenomenon. States often apply for authorization of several programs at once. Because more programs have become available for authorization over time, later authorizers tend to be more completely authorized. This correlation makes the number of programs authorized an imperfect measure of desire for authorization.

Two measures of authorization are shown for RCRA in Tables 3 and 5: the date of authorization for permitting under the base RCRA permitting program and the total percentage of RCRA for which the state is authorized. RCRA too shows no sign of the hypothesized U-shaped relationship between authorization and LCV scores. The only statistically significant association is with conservation group membership: there is a 
negative and statistically significant correlation between membership and year of authorization. As with CWA authorization, greener states get RCRA authorization earlier.

\section{Authorization and federal stringency.}

An alternative test of the hypothesis that desired stringency determines authorization uses variation in federal stringency. If changes in the federal administration change the expected federal stringency, they might also change the likelihood that states seek to authorize.

Table 6 tests for this effect by examining authorizations by administration. The table reports the total number of states authorizing and the average annual hazard rate (the share of the remaining states to authorize during each year) in each administration. After an initial flurry of authorization, the rates seem to stabilize, except that no states authorized under the first President Bush. ${ }^{9}$

The most interesting column in Table 6 is the final column, which reports the greenness of authorizing states relative to the pool of states remaining eligible. States that authorized during the Reagan years have considerably higher average LCV scores than states that did not to authorize at that time, whereas states that authorized during the Clinton years have considerably lower average scores. This pattern would be consistent with states authorizing to increase the stringency of their programs when federal efforts were likely to be relatively lax and authorizing to relax their programs when federal efforts were expected to be more stringent. The means are based on small numbers of states in both the numerator and denominator so do not offer proof, but are suggestive.

In addition, the final column in Table 6 also suggests that federal regulators do not impose their preferences on who gets to authorize. The patterns are the reverse of what one might expect if stringent administrations only authorized stringent states.

\footnotetext{
${ }^{9}$ The small number of states authorizing annually and relatively brief period may mean that the lull during the first Bush Administration is simply the result of chance.
} 


\section{B. Differences in desired targeting}

Another motivation for a state to seek authorization is to target the program differently than the federal government would. Although there is not a clean distinction between targeting and overall stringency of the program, some motivations for authorization seem distinct from an overall desire for greater or less environmental quality than the federal government would provide. The previous literature suggests two factors that may drive states to desire a different targeting — differences in objectives because of interstate spillovers and the informational advantages of the states. ${ }^{10}$

\section{Interstate spillovers.}

The objective function of state governments may encompass only the welfare of their residents, whereas the federal government's objective is the welfare of the entire country. This difference in objective functions plays an important role in the fiscal and environmental federalism literatures. Inefficient competition, mentioned above in the context of stringency, may be one consequence of this difference in objective functions. Another possible consequence is the underprovision of public goods for which there are substantial spillovers across jurisdictions. ${ }^{11}$ The magnitude of these spillovers is a central question in the literature on the problem of assigning functions to different levels of government (Oates, 1972; McKinnon and Nechyba, 1997). Unlike education and public safety, where the spillovers may be vague, environmental spillovers are tangible: physical transportation of pollution across state lines.

The effect of these interstate pollution spillovers on regulation and environmental quality is an active area of recent research. Several papers have found evidence that states free ride on their neighbors with transboundary pollution. Gray and Shadbegian (2002) examine several measures of pollution and regulatory activity from pulp and paper plants. They find evidence of higher air pollution (sulfur dioxide) and water pollution (total

\footnotetext{
${ }^{10}$ Both of these differences presume that the objective function optimized by state regulators is similar to the federal objective function. However, different political pressures at state and federal levels might result in different desired targeting of regulations. Given the large number of possible hypotheses about political differences, it is difficult to tackle this possibility empirically.

${ }^{11}$ Although the presence of a spillover is often a justification for assigning controls to a higher level of government, Dinan and Tawil (2003) investigate the success of creating regional institutions to maintain some of the benefits of decentralization.
} 
suspended solids) when the plant is near a state border or more benefits accrue to out-ofstate residents. For regulatory activity, they expect the reverse effects, indicating less attention to plants with large spillovers, but do not find them. Helland and Whitford (2002) examine releases of toxic chemicals reported by industrial facilities. They find that plants in border counties have 18 percent higher releases into air and 10 percent higher into water, consistent with a model in which states maximize the within-state welfare. Sigman (2002) examines in-stream water quality and finds evidence of free riding in pollutants regulated under the CWA. There is also evidence that authorization may allow free riding: pollution is elevated in rivers upstream of state borders in authorized states, but not in unauthorized states. Thus, these studies suggest that state use their discretion to free ride.

A desire to free ride could motivate authorization. In particular, states may wish to impose laxer controls near state borders. Thus, we would expect states with extensive spillovers to desire to authorize preferentially.

To test this hypothesis, we need a measure of the extent of spillovers faced by different states. Tables 4 and 5 present two measures of the extent of the spillover. The first measure is the area of the state. Larger states likely internalize more of the environmental benefits of pollution control than smaller states because it is farther to the border for the typical location in a large state. Thus, large states' objectives deviate less from federal objectives, giving large state less incentive to authorize.

States with CWA authorization are statistically significantly smaller than unauthorized states (Table 4) and the number of CWA program is negatively related to state area. These results are both consistent with the hypothesis that state authorize to free ride. However, removing unauthorized Alaska from the calculation reverses the results and makes the difference not statistically significant.

There is no evidence of an effect of state area on RCRA authorization levels. The principal benefits of RCRA are from reduced groundwater pollution and may be quite localized to the immediate area of management facilities. Thus, environmental spillovers may be small even for small states under this program, with the result that they do not motivate authorization under RCRA. 
A second measure of the extent of spillovers under CWA is the location of the state relative to the coast. Spillovers in the benefits of water pollution control are likely to be greatest for interior states, where rivers almost always flow through other states. Thus, interior states would authorize earlier under the CWA if free riding is a motivation. Table 4 presents the frequency with which authorized and unauthorized states are on the coast. There is no difference between the two groups and thus a failure to support spillovers as a cause of decentralization.

\section{Informational advantages.}

A central justification for decentralization of any public policy is that state or local decision-makers have better information than federal authorities and thus will create more efficient policy. In environmental policy, better information could lead state regulators to wish for higher or lower stringency than the federal government and thus may simply be a reason for the differences in overall desired stringency discussed above. However, better information may also lead to differences in how regulations are implemented and enforced for a given average stringency.

Direct measurements of differences in information are impossible to construct because the researcher can never hope for better data than state and federal authorities. However, heterogeneity in the costs of complying with a regulation may increase the value of a state's informational advantage. Because RCRA and CWA rely on standards rather than economic incentive instruments, regulators must allocate pollution control responsibilities across polluting facilities. If states have an informational advantage, they will be able to allocate reductions more cost effectively than federal regulators. The savings they can achieve is likely to be greater when polluters have very disparate control costs. Thus, the incentives to take control of the assignment of pollution control responsibilities may be strongest in diverse states.

Although there is also no direct information on cost heterogeneity within states, industrial diversity in a state might raise the heterogeneity in compliance costs. To measure diversity, I created Herfindahl indices of manufacturing income in the state, using the shares of state income from each two-digit SIC industry. A higher value of this index indicates a less diverse state. As might be expected, the index has negative 
correlations (not shown) with state area and population, although neither correlation is statistically significant at 5 percent.

Table 4 reports the difference in this measure for states that are currently authorized under the base CWA program and those that are not. The means suggest less diversity in authorized states, which is inconsistent with the hypothesis, but the difference is not statistically significant. The correlations in Table 5 also do not provide much support the hypothesis. The Herfindahl is not statistically significantly correlated with any of the authorization measures, except RCRA authorization date: states with less diversity (higher Herfindahls) do have later authorization years, consistent with the hypothesis.

Failure to find a strong effect here may reflect the weakness of using industrial diversity as a proxy for variability in pollution control costs. For example, hazardous waste regulation under RCRA focuses on activities undertaken by waste management facilities rather than activities at the industrial facilities that generate hazardous waste (Sigman, 2000). Many waste management facilities are separate from production facilities and may import much of their waste from out of state. Thus, the relevant RCRA heterogeneity may be the diversity of management facilities and the wastes they manage.

\section{Regulatory considerations}

Two final determinants of authorization may result from the goals and constraints facing the state regulatory agency.

\section{Bureaucratic priorities.}

The desire for authorization may arise from goals that do not depend on altering the program. It could simply be a matter of the state environmental bureaucracy's desire to expand its functions. ${ }^{12}$ States with better-organized environmental agencies may have greater means and desire to expand functions by authorizing.

\footnotetext{
${ }^{12}$ In most states, the relevant bureaucracy is called the Department of Environmental Quality or the Department of Environmental Protection. A few states combine these functions with a public health or natural resource department.
} 
Although it is possible to obtain data on employees and funding of the state departments responsible for environmental regulation, larger bureaucracies would naturally result from authorization. As a result, we have no direct measures of bureaucratic impetus. However, states with greener preferences are likely to have betterorganized bureaucracies. Thus, the ability of these bureaucracies to expand may partly explain the association (discussed above) between green preferences and early authorization.

\section{Economies of scale in regulation.}

Economies of scale in regulation may be an additional bureaucratic determinant of authorization. If implementation and enforcement involve substantial fixed costs (in staffing offices, for example), states that expect to undertake more extensive programs may find authorization more attractive. Scale economies themselves do not justify authorization because the federal government enjoys the greatest economies, but they might explain which otherwise-motivated states authorize.

To test scale economies, we would like a measure of the size of the program in the states. The workload in permitting, monitoring, and enforcement depends on the number of regulated entities. For the number of regulated entities, I use the number of NPDES permits under CWA and the number of hazardous waste management facilities under RCRA. Table 4 reports that authorized CWA states have about twice as many water polluters on average as unauthorized states, but the difference is not statistically significant. Table 5 also contains some evidence of scale economies: there is a positive correlation between the number of regulated entities under each program and the extent of authorization, which is statistically significant at 10 percent. However, there is no correlation with year of authorization under either program.

\section{Authorization outcomes}

To understand the empirical consequences of decentralization of environmental policies, we need to know not only what drives states to authorize, but what they do with this authority when they have it. What are the results of authorization? Although no 
previous study concentrates on the role of authorization, a few studies that explore other questions have relevant results because they include authorization status as a control variable. All the studies focus on water pollution.

DeShazo (2002) examines the permit levels written for pulp and paper plants under CWA and finds little evidence of an effect of authorization on this measure of stringency in implementation. Permits written by states contain higher allowable pollution, but the result is only statistically significant in one of eight models he estimates.

Whereas DeShazo studies permit writing, Helland (1998) studies inspections. He finds generally positive but statistically insignificant effects of state authorization on the frequency of inspections and on the intensity of inspections when they occur.

Sigman (2002) estimates an equation that predicts water quality in rivers. Water quality summarizes the combined effects of permits and inspections, but may also be sensitive to state policies not under CWA (such as land use policies). CWA authorization in the state is associated with overall lower levels of pollution: authorization raises the number of monitoring stations with swimmable water (the best water quality) by more than 60 percent. The direction of causality is unclear. Authorized states may be more stringent than the federal government or the federal government may preferentially grant authorization requests when the state achieves good water quality.

Thus, the literature is mixed about the implications of authorization. Although some observers have asserted that authorization reduces environmental quality, empirical studies find either no association with authorization or possibly an improvement. However, a final judgment on this question remains for further study. In particular, it will be necessary to disentangle the direction of causality between authorization status and the operation of state environmental programs.

\section{Conclusion}

Authorization is perhaps the most important decentralization of environmental regulations in the United States. Federal statutes cover most major forms of pollution, so the remaining room for state decision-making is largely as implementers and enforcers of federal standards. This paper has explored the determinants of authorization --- as an 
indicator of what states intend to do with discretion over environmental policy --- and the limited empirical evidence on the effects of authorization.

The results do not suggest any simple pattern for authorization. None of the hypotheses advanced provide such a compelling explanation that they have strong and consistent influences on all of the measures of authorization status under CWA or RCRA.

However, there is evidence about some effects of authorization that states anticipate. States may authorize to increase the stringency of their programs: states with more conservation group members authorized earlier under both programs. Green states also appear to authorize during less green administrations and vice versa. These results suggest that decentralization allows states to break away from federally uniform standards. In addition, they suggest that this delegation is desirable because it allows welfare-based heterogeneity in stringency. More research is needed to complete the story by exploring whether increased stringency is an outcome of authorization. However, identifying the effects of authorization will be a difficult task because of the endogeneity of authorization status.

I do not find much evidence that states authorize to capitalize on informational advantages that they have relative to the federal government. Authorization is neither more extensive nor earlier authorization in states with greater industrial diversity, which I take as an indicator of the state's informational advantage. However, this result should be tested with measures of diversity more closely linked to the regulations, such as diversity in the hazardous waste managed by the state.

Finally, there is little evidence here that states seek authorization to free ride. Authorization is not concentrated in geographically small states or inland states. This conclusion is at odds with recent research that points to free riding in transboundary pollution. Additional research is desirable to identify the mechanisms through which states free ride and its implications for decentralization of policies, including decentralization through authorization. 


\section{References}

Besley, Timothy and Stephen Coate. "Centralized vs. Decentralized Provision of Local Public Good: A Political Economy Analysis.” NBER Working Paper No. 7084. Cambridge, MA: National Bureau of Economic Research, 1999.

Crandall, Robert W. Manufacturing on the Move. Washington, DC: Brookings Institution, 1993.

DeShazo, J.R. "A Positive Theory of Standard-Setting Behavior with an Application to the Clean Water Act." Mimeo, 2002.

Dinan, Terry M., Maureen L. Cropper, and Paul R. Portney. "Environmental Federalism: Welfare Losses from Uniform National Drinking Water Standards." In Environmental and Public Economics: Essays in Honor of Wallace E. Oates, edited by Arvind Panagariya et al., 13-31. Cheltenham, U.K.: Edward Elgar, 1999.

Dinan, Terry and Natalie Tawil. "Resolving Environmental Externalities with Regional Decisionmaking: Controlling Ground-Level Ozone." National Tax Journal 2003 forthcoming.

Esty, Daniel C. "Revitalizing Environmental Federalism." Michigan Law Review 95 No. 3 (December 1996): 570-653.

Farber, Daniel. "Taking Slippage Seriously: Noncompliance and Creative Compliance in Environmental Law." Harvard Environmental Law Review 23 No. 2 (1999): 297-325.

Flatt, Victor B. "A Dirty River Runs Through It (The Failure of Enforcement in the Clean Water Act)."Boston College Environmental Affairs Law Review 25 (1997): $1-45$.

Freeman, A. Myrick. "Water Pollution Policy." In Public Policies for Environmental Protection, Second Edition, edited by Paul R. Portney and Robert N. Stavins, 169-213. Washington, DC: Resources for the Future, 2000.

Gray, Wayne and Ronald J. Shadbegian. "“Optimal' Pollution Abatement - Whose Benefits Matter, and How Much?” NBER Working Paper No. 9125. Cambridge, MA: National Bureau of Economic Research, 2002.

Margaret Rosso Grossman. "Environmental Federalism in Agriculture: The Case of Pesticide Regulation in the United States." In Environmental Policy with Political Integration: The European Union and the United States, edited by John B. Braden, Henk Folmer and Thomas Ulen, 274-304. Cheltenham,UK: Edward Elgar, 1996. 
Hall, Bob and Mary Lee Kerr. The 1991-92 Green Index. Washington, DC: Island Press, 1991.

Helland, Eric. "The Revealed Preferences of State EPAs: Stringency, Enforcement, and Substitution." Journal of Environmental Economics and Management 35 No.3 (May 1998): 242-261.

Helland, Eric and Andrew B. Whitford. "Pollution Incidence and Political Jurisdiction: Evidence from the TRI." Mimeo, 2002.

Levinson, Arik. "Environmental Federalism: A Status Report and Some New Evidence." National Tax Journal 2003 (forthcoming).

McKinnon, Ronald and Thomas Nechyba. "Competition in Federal Systems: The Role of Political and Financial Constraints." In The New Federalism: Can the States be Trusted? edited by John A. Ferejohn and Barry R. Weingast, 3-61. Stanford, CA: Hoover Institution Press, 1997.

Oates, Wallace E. "An Essay on Fiscal Federalism.” Journal of Economic Literature 37 No. 3 (September 1999): 1120-1149.

Oates, Wallace E. “A Reconsideration of Environmental Federalism.” RFF Discussion Paper 01-54, Washington, DC: Resources for the Future, 2001.

Pashigian, B. Peter. "Environmental Regulation: Whose Self-Interests Are Being Protected?" Economic Inquiry 23 (July 1995): 551-584.

Revesz, Richard. "Federalism and Environmental Regulation: A Public Choice Analysis." Harvard Law Review 115 No. 2 (December 2001): 553-642.

Sigman, Hilary. "Federalism and Transboundary Spillovers: Water Quality in U.S. Rivers." Mimeo, 2002.

Sigman, Hilary. "Hazardous Waste and Toxic Substance Policies." In Public Policies for Environmental Protection, Second Edition, edited by Paul R. Portney and Robert N. Stavins, 215-259. Washington, DC: Resources for the Future, 2000.

Strumpf, Koleman S. and Felix Oberholzer-Gee. "Endogenous Policy Decentralization: Testing the Central Tenet of Economic Federalism." Journal of Political Economy 110 No. 1 (February 2002): 1-36.

Wilson, John Douglas. “Theories of Tax Competition.” National Tax Journal. 52 No. 2 (June 1999): 269-304. 
U.S. General Accounting Office. EPA and the States: Environmental Challenges Require a Better Working Relationship. Washington, DC: U.S. General Accounting Office, 1995.

U.S. General Accounting Office. Water Pollution: Differences among the States in Issuing Permits Limiting the Discharge of Pollutants. Washington, DC: U.S. General Accounting Office, 1996. 
Table 1. Variability in NPDES discharge limits for municipal wastewater facilities

\begin{tabular}{lrrrll}
\hline Pollutant & $\begin{array}{c}\text { Minimum } \\
\text { limit } \\
\text { (lbs/day) }\end{array}$ & $\begin{array}{c}\text { Maximum } \\
\text { limit } \\
\text { (lbs/day) }\end{array}$ & $\begin{array}{c}\text { Ratio of } \\
\text { max to } \\
\text { min }\end{array}$ & $\begin{array}{c}\text { State with } \\
\text { minimum limit }\end{array}$ & $\begin{array}{c}\text { State with } \\
\text { maximum } \\
\text { limit }\end{array}$ \\
\hline Cadmium & 0.321 & 1.334 & 4 & W. Virginia & Arizona \\
Copper & 0.184 & 6.963 & 38 & Massachusetts & W. Virginia \\
Lead & 0.025 & 7.800 & 312 & W. Virginia & Ohio \\
Mercury & 0.00016 & 0.126 & 750 & N. Carolina & W. Virginia \\
Zinc & 0.834 & 60.04 & 71 & W. Virginia & W. Virginia \\
\hline \hline
\end{tabular}

Source: U.S. GAO, 1996.

Note: For facilities with discharge range between 1.4 and 2.5 million gallons/day.

Table 2. Authorization status for different programs under CWA

\begin{tabular}{lr}
\hline \multicolumn{1}{c}{ Programs authorized } & $\begin{array}{c}\text { Number } \\
\text { of states }\end{array}$ \\
\hline None & 6 \\
NPDES base, General permits & 2 \\
NPDES base, General permits, Federal facility NPDES & 9 \\
NPDES base, General permits, Pretreatment & 3 \\
NPDES base, General permits, Federal facility NPDES, Pretreatment & 25 \\
NPDES base, General permits, Federal facility NPDES, Pretreatment, Biosolids & 5 \\
\hline \hline
\end{tabular}

Table 3. Relationship between CWA and RCRA authorization status and League of Conservation Voters (LCV) scores

\begin{tabular}{|c|c|c|c|c|}
\hline \multirow[b]{2}{*}{ Authorization status measure } & \multicolumn{4}{|c|}{$\begin{array}{c}\text { League of Conservation Voter Score for } \\
\text { House Delegation, } 2000\end{array}$} \\
\hline & $\begin{array}{l}\text { Lowest } \\
\text { quartile }\end{array}$ & $\begin{array}{l}\text { Second } \\
\text { quartile }\end{array}$ & $\begin{array}{l}\text { Third } \\
\text { quartile }\end{array}$ & $\begin{array}{l}\text { Highest } \\
\text { quartile }\end{array}$ \\
\hline \multicolumn{5}{|l|}{ Clean Water Act } \\
\hline Base programs authorized & $75 \%$ & $91 \%$ & $92 \%$ & $92 \%$ \\
\hline Mean year of authorization & 1984 & 1978 & 1977 & 1978 \\
\hline Mean number of programs authorized & 3.08 & 3.58 & 3.08 & 3.46 \\
\hline \multicolumn{5}{|l|}{ Resource Conservation and Recovery Act } \\
\hline Mean year base program authorized & 1986 & 1984 & 1986 & 1987 \\
\hline Mean percentage authorization & $77 \%$ & $70 \%$ & $71 \%$ & $54 \%$ \\
\hline
\end{tabular}


Table 4. Means of selected state characteristics by CWA authorization status in 2002

\begin{tabular}{lrrr}
\hline \hline & Authorized & $\begin{array}{c}\text { Not } \\
\text { authorized }\end{array}$ & $\begin{array}{c}\text { p-value of } \\
\text { difference }\end{array}$ \\
\hline League of Conservation Voters score for House delegation & 44.75 & 32.5 & .29 \\
Conservation group membership per thousand & 8.2 & 10.8 & .10 \\
State area (million square miles) & 61 & 152 & .01 \\
Coastal state & .46 & .5 & .84 \\
Manufacturing income Herfindahl index & 13.1 & 10.8 & .45 \\
Number of CWA permitted facilities & 141 & 73 & .16 \\
\hline \hline
\end{tabular}

Table 5. Correlations between authorization status and state characteristics

\begin{tabular}{lrrrr}
\hline \hline & \multicolumn{2}{c}{ CWA } & \multicolumn{2}{c}{ RCRA } \\
\multicolumn{1}{c}{ State characteristic } & $\begin{array}{c}\text { Base program } \\
\text { authorization } \\
\text { year }\end{array}$ & $\begin{array}{c}\text { Number of } \\
\text { programs } \\
\text { authorized }\end{array}$ & $\begin{array}{c}\text { Base program } \\
\text { authorization } \\
\text { year }\end{array}$ & $\begin{array}{c}\text { Percent } \\
\text { authorization }\end{array}$ \\
\hline LCV score for House delegation & -.232 & .047 & -.137 & .185 \\
Conservation group membership & $-.317^{* *}$ & $-.370^{* *}$ & $-.285^{* *}$ & .203 \\
State area & .167 & $-.273^{*}$ & -.209 & -.087 \\
Manufacturing Herfindahl & -.034 & .100 & $.248^{*}$ & -.068 \\
Number of water polluters & .245 & $.238^{*}$ & & $.234^{*}$ \\
$\begin{array}{l}\text { Number of hazardous waste } \\
\text { management facilities }\end{array}$ & & & -.041 & \\
\hline \hline
\end{tabular}

Notes: $* *$ and $*$ indicate statistically significant at $5 \%$ and $10 \%$ respectively. Authorization year only for authorized states.

Table 6. CWA authorization by Administration

\begin{tabular}{lrrr}
\hline Administration & $\begin{array}{c}\text { Number of } \\
\text { states } \\
\text { authorizing }\end{array}$ & $\begin{array}{c}\text { Annual } \\
\text { hazard rate }\end{array}$ & $\begin{array}{c}\text { LCV scores } \\
\text { relative to } \\
\text { remaining } \\
\text { states }\end{array}$ \\
\hline Ford & 27 & .184 & 1.14 \\
Carter & 5 & .061 & .96 \\
Reagan & 6 & .050 & 1.45 \\
Bush & 0 & .000 & - \\
Clinton & 5 & .065 & .48 \\
\hline \hline
\end{tabular}




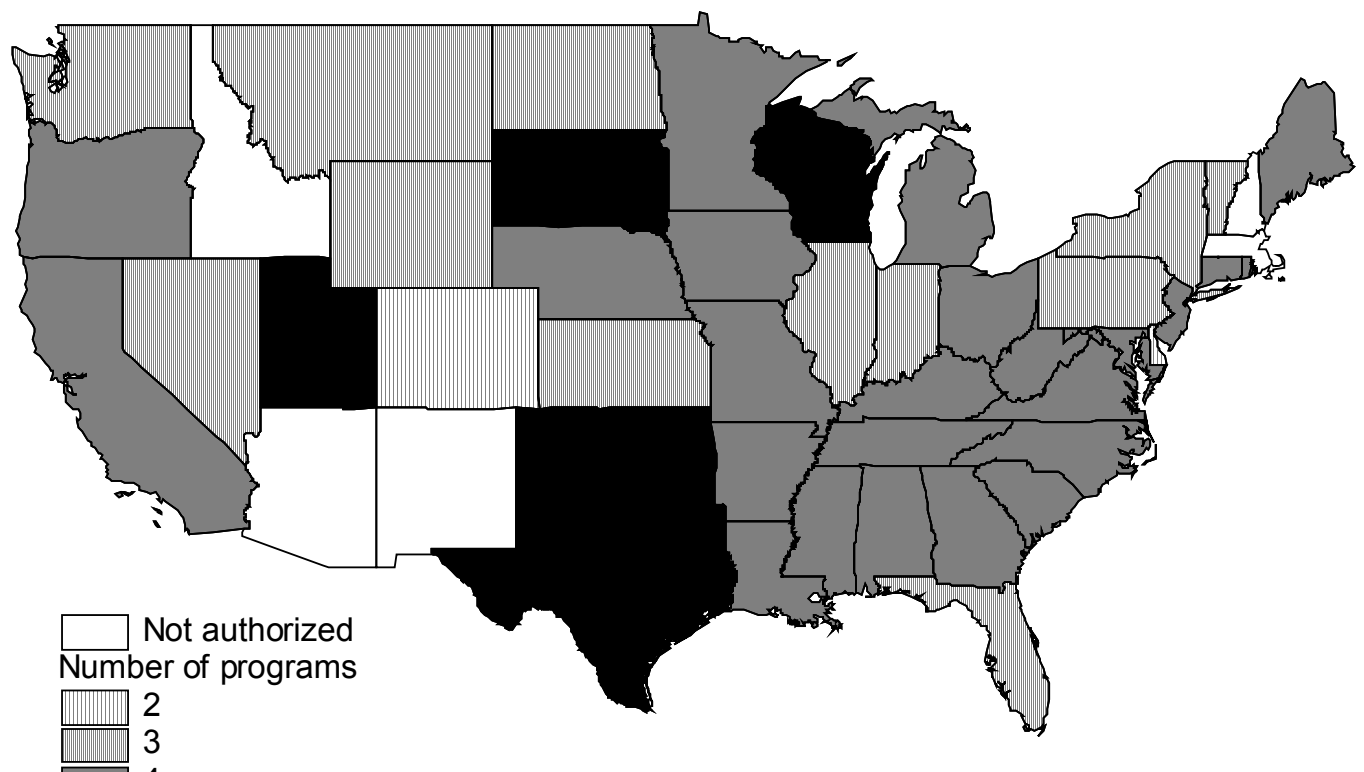

Alaska: Not authorized

Hawaii: 4 programs authorized

Figure 1: Number of CWA programs authorized in 2002 


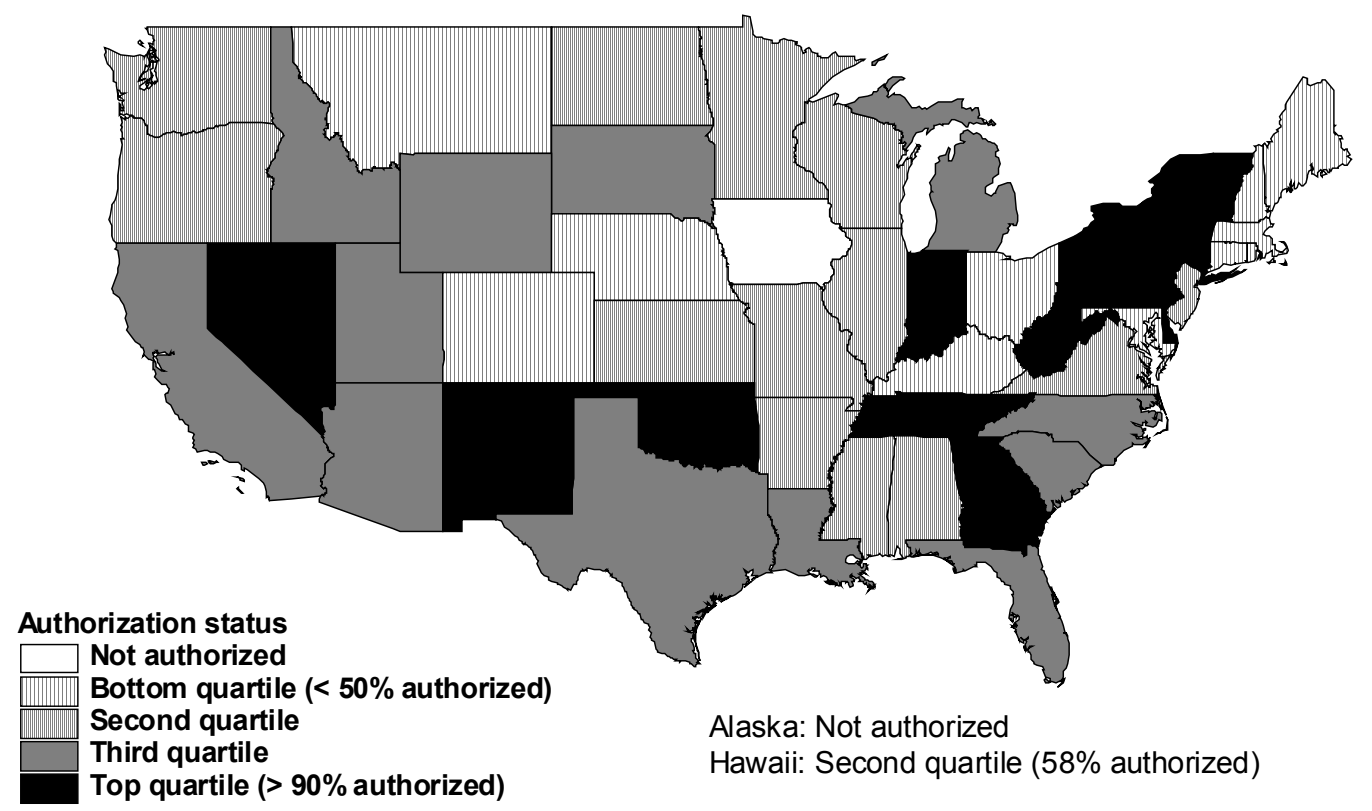

Figure 2: RCRA percentage authorization in 2002, by quartile 